\title{
Quality Comparison and Acceptability of Yoghurt with Different Fruit Juices
}

\author{
Md. Nur Hossain ${ }^{1 *}$, Md. Fakruddin ${ }^{1}$ and Md. Nurul Islam² \\ ${ }^{1}$ Institute of Food Science and Technology, BCSIR, Dhaka, Sri Lanka \\ ${ }^{2}$ Department of Food Technology and Rural Industries, Bangladesh Agricultural University, Mymensingh-2202, Bangladesh
}

\begin{abstract}
Yoghurt is consumed worldwide for its nutritional and health benefits. The research was conducted to prepare fruit yoghurt with different level of fruit juice $(5 \%, 10 \%$ and $15 \%)$ of different fruits (strawberry, orange and grape). Different physico-chemical and microbiological characteristics were analyzed to assay the quality of the yoghurts. Yoghurts fortified with $10 \%$ orange juice was the best in quality among the others. The smell and taste, body and consistency and color and texture of the fruit yoghurts were equally acceptable. $10 \%$ and $15 \%$ strawberry fruit yoghurt contain more acid and its texture was cracked down in refrigeration temperature. The moisture and acidity content of fruit yoghurts were increased than plain yoghurt because of high content of these in the fruits. The fat, protein, carbohydrates and ash content of strawberry and orange fruit yoghurt were decreased than normal plain yoghurt. But the carbohydrates content of grape yoghurt were increased because grape contains more sugar than milk and other two fruits. Statistical analysis showed that yoghurt with $10 \%$ orange juice was more acceptable than others comparing all quality characteristics. The microbiological quality of the fruit yoghurts was also acceptable because of acid content of the fruits. In case of strawberry yoghurt, fruit juice concentration more than $5 \%$ was not suitable for fruit yoghurt because that are highly acidic and curd was cracked down at refrigerated condition. This formulation and quality findings will be helpful to set up fruit yoghurt industry.
\end{abstract}

Keywords: Quality; Acceptability; Fruit juice; Yoghurt

\section{Introduction}

Of all, cultured milk products, yoghurts are well known and most popular worldwide [1,2]. Like milk, yoghurt is a healthy and delicious food due to its high nutritive and therapeutic value [3]. Due to low lactose content yoghurt is easily digestible and palatable than milk. Yoghurt is valued for controlling the growth of bacteria and in curing of intestinal disease like constipation, diarrhea \& dysentery, anticarcinogenic effect \& lowering of blood cholesterol [4]. Flavor, texture and aroma of yoghurt depend upon the country of origin as well as other factors including raw materials quality, manufacturing process and the strains involved [5]. Good quality yoghurt should be smooth, glossy surface, no crakes or holes on the top of yoghurt, no whey syneresis, no off flavor or odor, clean layer on the surface of yoghurt. Yoghurt is generally considered as a safer product and its unique flavor appeals to so many that consideration is being given by nutritionists to incorporate inexpensive source of nutrients to make it an almost complete food [6].

Preparation of fruit yoghurt has been investigated by a number of researchers in different parts of world [7,8]. But in Bangladesh no research work has yet been done on the manufacture of yoghurt incorporating strawberry, orange and grape juice. For this reasons the present study was designed to manufacture fruit yoghurt fortified with different levels of strawberry, orange and grapes juice with whole milk and to compare their qualities on the basis of physical, chemical and microbial parameters.

\section{Material and Methods}

The experiment was conducted in the Laboratory of the Department of Food Technology \& Rural Industries and Department of Dairy Science, Bangladesh Agricultural University, Mymensingh. Fresh milk was collected from Dairy Farm of Bangladesh Agricultural University, Mymensingh. Fruits for juice preparation, sugar, and starter culture collected from local market.

\section{Preparation of fruit juice (Strawberry, Orange and Grape)}

Collected Strawberry (Fragaria alpina), Orange (Citrus sinensis) and Grape (Vitis vinifera) fruit was washed with clean water and the skin was separated with the help of knife aseptically. The seeds were removed from the Strawberry and Oranges. Black spots were removed from strawberry. Strawberries were blended and oranges and grapes juice was extracted by juicer. After blending, the juice was filtered with clean cloth (hot water washed). These were kept in plastic containers and stored at freezing temperature $\left(-20^{\circ} \mathrm{C}\right)$ until preparation of dahi (yogurt).

Preparation of plain dahi (control) and fruit (Strawberry, Orange and Grape) dahi

Whole milk was pasteurized and heated to reduce about one-third of its original volume. Sugar was added to the milk at the rate of $12 \%$ after boiling. During heating milk was stirred continuously with the help of a stirrer to avoid formation of cream layer. After desired heating milk pan was taken out from the heater and allowed to cool. When the temperature was about $40^{\circ} \mathrm{C}$, then milk was divided into four equal portions and a different type of dahi was prepared from each portion. The fruit (Strawberry, Orange and Grape) juice which is previously pasteurized was incorporated into yoghurt at 5\%,10\% and $15 \%$ level

*Corresponding author: Md. Nur Hossain, Scientific Officer, Industrial Microbiology Laboratory, Institute of Food Science and Technology (IFST), Bangladesh Council of Scientific and Industrial Research (BCSIR) Dhaka, Bangladesh, E-mail mnhossain84@gmail.com

Received April 23, 2012; Accepted July 24, 2012; Published July 29, 2012

Citation: Hossain MN, Fakruddin M, Islam MN (2012) Quality Comparison and Acceptability of Yoghurt with Different Fruit Juices. J Food Process Technol 3:171. doi:10.4172/2157-7110.1000171

Copyright: (C 2012 Hossain MN, et al. This is an open-access article distributed under the terms of the Creative Commons Attribution License, which permits unrestricted use, distribution, and reproduction in any medium, provided the original author and source are credited. 
in different cups except control [9]. Juice was added before incubation with starter culture as suggested by Guven \& Karaca [10]. Milk was inoculated with desirable proportion of starter culture (2\%), which was collected from local market. The plastic cups were pre-washed with boiled water before use. The samples were incubated at $37^{\circ} \mathrm{C}$ until the complete curd formation/coagulation of yoghurt (8-12 hrs). The yoghurt samples were stored at about $4^{\circ} \mathrm{C}$ at refrigeration until used.

\section{Physical tests}

After complete curd formation, the samples were judged separately by a team of experienced judges for organoleptic parameters including smell and taste, body and consistency, color and texture and data were analysed statistically according to Hossain et al. [11].

\section{Chemical analysis of fresh milk and different type dahi}

Moisture, Total Solids (TS) and Ash content of the different type of milk and juice samples were determined according to AOAC [12]. Fat percent was determined by Babcock method using the procedure described by Aggarwala and Sharma [13]. Acidity was determined by titration with $0.1 \mathrm{~N}$ sodium hydroxide solution using the procedure by Aggarwala and Sharma [13]. Crude protein was determined by Kjeldahl described by Rangana [14] procedure. Total carbohydrate content of the sample was determined by subtracting the measured protein, fat, ash and moisture from 100 [15]. $\mathrm{pH}$ was measured with the help of a $\mathrm{pH}$ meter (HANNA instruments, HI 8424, microcomputer $\mathrm{pH}$ meter). Specific gravity of milk was determined by lactometer.

\section{Microbiological tests}

Prepared yoghurt samples were examined for total viable count, total coliform count, total yeast and mold count. For total viable count of bacteria, colony count method was used according to "Laboratory Methods in Food Microbiology" [16]. The total number of viable bacteria per gram of yoghurt was obtained by multiplying the number of colony forming units ( $\mathrm{CFU}$ ) on the plate with respective dilution factor and then was converted into logarithmic form. Total coliform (MPN/g) was counted by MPN (Most probable number) method. Yeast and mold count were determined according to the "Standard Methods for Examination of Dairy Products" by American Public Health Association [17].

\section{Results}

\section{Chemical analysis of milk}

Quality of Milk used for yoghurt production was analyzed before use. Moisture, total solid, fat, protein, ash, lactose, acidity $\mathrm{pH}$, Solid Non-Fat (SNF) and specific gravity were determined. Results of chemical analysis of milk are shown in (Table 1). The results are more or less similar to other researcher. Protein percentage of raw milk samples was 3.3, which is within the normal range of 2.3 to 4.4 [18]. The average specific gravity of milk samples was 1.03 (Table 1). Similar specific gravity value was obtained by Biswas [19] for Bangladesh Agricultural University, dairy farm milk. Mean acidity of the experimental samples was 0.17 percent (Table 1 ) which is within the normal range.

\section{Comparison of physical characteristics of fruit yoghurts}

Plain yoghurt (no fruit juice added) was compared with yoghurts incorporating different concentrations (5\%,10\% \& 15\%) of juices of strawberry $\left(\mathrm{S}_{1}, \mathrm{~S}_{2} \& \mathrm{~S}_{3}\right)$, orange $\left(\mathrm{O}_{1}, \mathrm{O}_{2} \& \mathrm{O}_{3}\right)$ and grape $\left(\mathrm{G}_{1}, \mathrm{G}_{2} \& \mathrm{G}_{3}\right)$ for average smell and taste, body and consistency and color and flavor by a team of judges. Results of the organoleptic tests were presented in (Table 2).

\section{Yoghurts with 5\% fruit juice}

Statistical analysis shows that there was significant difference ( $p>0.05$ ) among the smell and taste and body and consistency score of different types of yoghurt. Highest smell and taste score (45.5) was recorded in case of yoghurt with $5 \%$ orange juice $\left(\mathrm{O}_{1}\right)$. On the other hand, lowest score (14.4) was seen in case of yoghurt with $5 \%$ strawberry juice $\left(\mathrm{S}_{1}\right)$. The $5 \%$ grape juice yoghurt $\left(\mathrm{G}_{1}\right)$ is also equally acceptable. Similar results were also reported by Keating and White [20]. The highest score of body and consistency (27.1) was found in $\mathrm{O}_{1}$ and $\mathrm{G}_{1}$ type yoghurt and the lowest score (22.6) was seen in case $\mathrm{S}_{1}$ type yoghurt. There was no significant difference for color and texture scores of different types of fruit yoghurt. From (Table 2), the highest score (19.2) was found for $\mathrm{O}_{1}$ type and the lowest score (14.4) was given for $\mathrm{S}_{1}$ type of yoghurt. Texture of strawberry fruit yoghurt was crack down due to high content of acid.

\section{Yoghurts with $10 \%$ fruit juice}

Statistical analysis shows that there was significant difference $(\mathrm{P}<0.05)$ among the smell and taste scores of different types of yoghurt. Higher smell and taste score (47.8) was recorded incase of $\mathrm{O}_{2}(10 \%$ orange) type yoghurt. On the other hand, lowest score (33.5) was seen in case of $S_{2}(10 \%$ strawberry) type yoghurt. The result of this experiment indicates that smell and taste of yoghurt is optimum level due to the addition of $10 \%$ orange juice which gave the best result. $10 \%$ grape juice yoghurt also gives good quality but not significantly different. The result agrees with the work of Desai et al. [7] who found that smell and taste of mango and pineapple yogurt were higher than that of control yoghurt. There was no significant difference among the body and consistency scores of different types of fruit yoghurt with $10 \%$ juice.

Optimum body and consistency of yoghurt was found in yoghurt with $10 \%$ orange juice. There was significant difference $(\mathrm{P}<0.01)$ in color and texture scores of different types of fruit. The highest score was found for $10 \%$ orange juice yoghurt. The result of this experiment supports the findings of Desai et al. [7] who observed that addition of fruit juice improved the color and texture score of yoghurt. Considering all the quality parameters the highest score is given to yoghurt with $10 \%$ orange juice.

\section{Yoghurts with $15 \%$ fruit juice}

Average smell and taste scores of yoghurt samples containing 15\% fruit juice of strawberry $\left(\mathrm{S}_{3}\right)$, Orange $\left(\mathrm{O}_{3}\right)$ and grape $\left(\mathrm{G}_{3}\right)$ were 28.4 44.6 and 43.1 respectively compared to 41.6 of plain yoghurt (Table 2). Statistical analysis shows that there was significant difference $(\mathrm{P}<0.01)$ among the smell and taste scores of different types of yoghurt with 15\% juice. Higher smell and taste score (44.6) was recorded in case of $\mathrm{O}_{3}$ type yoghurt. On the other hand, lowest score (28.4) was seen in case of $\mathrm{S}_{3}$ type yoghurt. There was significant difference $(\mathrm{P}>0.05)$ among the body and consistency scores of fruit yoghurts. From (Table 2), the highest score (27.1) was found for $\mathrm{O}_{3}$ type and lowest score (15.2) was for $\mathrm{S}_{3}$ type yoghurt. The average color and texture score of yoghurt samples containing $\mathrm{P}, \mathrm{S}_{3}, \mathrm{O}_{3}$ and $\mathrm{G}_{3}$ fruit yoghurt were 17.2, 10.1, 19.2 and 15.4 respectively (Table 2). There was no significant difference among the color and texture scores of different types of fruit yogurt with $15 \%$ juice. 


\section{Comparison of chemical characteristics of fruit yoghurts}

Chemical characteristics are important indicators of quality measures of prepared yoghurt. Moisture, Total Solids, Total acidity, Fat, Protein, Carbohydrates and Ash content of the fruit yoghurt was determined. Results obtained are shown in (Table 3).

\section{Yoghurts with 5\% fruit juice}

Statistical analysis showed that the differences of acidity percentage among 5\% fruit yoghurts were not significant $(\mathrm{p}<0.01)$. Acidity decreased a little due to the addition of different type of fruit juice. The differences in fat percentage between plain yoghurt and yoghurt containing fruit juice were significant $(p>0.05)$. Maximum fat percent was seen in plain $(\mathrm{P})$ yoghurt and fat percent was found in fruit yoghurts was nearly equal. Generally fruit contains low level of fat. So the addition of fruit juice might have decreased the fat percent of fruit yoghurt. There were significant differences in total solids content among the different yoghurt samples. The highest value was recorded in case of $G_{1}$ type fruit yoghurt. This indicated that solid content increased with addition of grape juice. Overall ash content of yoghurt with $5 \%$ fruit juice was somewhat lower than that of plain yoghurt but differences in ash content between and among the treatments was significant $(\mathrm{p}>0.05)$. The protein content was decreased due to addition of fruit juice because fruit juice contains lower protein than milk. The protein content did not differ significantly ( $p>0.05$ ) among the different treatments. The carbohydrates content was highest in $\mathrm{G}_{1}$ type yoghurt and the lowest in plain $(\mathrm{P})$ yoghurt (Table 3 ).

\section{Yoghurts with $10 \%$ fruit juice}

The differences of acidity percentage among yoghurts with $10 \%$ fruit juice were not significant. Acidity increased a little due to the addition of different type of fruit juice. The differences in fat percent between plain yoghurt and yoghurt containing fruit juice at $10 \%$ concentration were significant $(\mathrm{P}>0.05)$. Maximum fat percent was seen in plain/control $(\mathrm{P})$ yoghurt and lowest fat percent was found in case of $\mathrm{O}_{2}$ and $\mathrm{G}_{2}$ type yoghurt. The highest value of total solid content was recorded in case of plain $(\mathrm{P})$ type and the value was decreased due to addition of juice. Overall ash content of yoghurt with $10 \%$ orange juice was somewhat lower than that of plain yoghurt but differences in ash content between and among the treatments was not significant $(\mathrm{P}>0.05)$. The average values of protein content of $\mathrm{P}, \mathrm{S}_{2}, \mathrm{O}_{2}$ and $\mathrm{G}_{2}$ types of yoghurt were $3.50,3.22,3.16$ and $3.16 \mathrm{~g}$ respectively (Table 3 ). The protein content did not differ significantly $(\mathrm{p}>0.01)$ among the different treatments. Statistical analysis showed that there were significant $(\mathrm{p}<0.05)$ differences among the fruit yoghurts with $10 \%$ juice as far as carbohydrate is concerned. The carbohydrate content was highest in $\mathrm{G}_{2}$ type yoghurt and the lowest in plain (P) yoghurt (Table 3 ).

\section{Yoghurts with 15\% fruit juice}

The average percentage of acidity of yoghurt samples $\mathrm{P}, \mathrm{S}_{3}, \mathrm{O}_{3}$ and $\mathrm{G}_{3}$ type were $0.66,0.81,0.79$ and 0.77 respectively (Table 3). Statistical analysis showed that the differences of acidity percentage among different treatments were not significant. The differences in fat percent between plain yoghurt and yoghurt containing fruit juice at $15 \%$ concentration were significant $(\mathrm{P}>0.05)$. Maximum fat percent (4.5) was seen in plain yoghurt and fat percent was found to gradually decrease in addition of fruit juice. Difference in the mean total solids percentage was significant among the different yoghurt samples. The highest value (27.17) was recorded in case of $15 \%$ grape yoghurt. Overall

\begin{tabular}{|c|c|c|c|c|c|c|c|c|c|c|}
\hline Compositions & $\begin{array}{c}\text { Moisture } \\
(\%)\end{array}$ & $\begin{array}{c}\text { Total solids } \\
(\%)\end{array}$ & $\begin{array}{c}\text { Fat } \\
(\%)\end{array}$ & $\begin{array}{c}\text { Protein } \\
(\%)\end{array}$ & $\begin{array}{c}\text { Ash } \\
(\%)\end{array}$ & $\begin{array}{c}\text { Lactose (CHO) } \\
(\%)\end{array}$ & $\begin{array}{c}\text { Acidity } \\
(\%)\end{array}$ & pH & SNF (\%) & Sp. gr. \\
\hline Raw milk & 87.46 & 12.54 & 4.16 & 3.32 & 0.71 & 4.26 & 0.17 & 6.8 & 8.38 & 1.029 \\
\hline
\end{tabular}

Table 1: Chemical quality of milk samples.

\begin{tabular}{|c|c|c|c|c|c|c|c|c|c|c|c|c|c|c|c|}
\hline \multirow{3}{*}{$\begin{array}{l}\text { Physical } \\
\text { characteristics }\end{array}$} & \multicolumn{15}{|c|}{ Different types of fruit yoghurt } \\
\hline & \multicolumn{5}{|c|}{$5 \%$ fruit juice } & \multicolumn{5}{|c|}{$10 \%$ fruit juice } & \multicolumn{5}{|c|}{$15 \%$ fruit juice } \\
\hline & $\mathrm{P}$ & $\mathrm{S}_{1}$ & $\mathrm{O}_{1}$ & $\mathrm{G}_{1}$ & LoS & $\mathrm{P}$ & $\mathrm{S}_{2}$ & $\mathrm{O}_{2}$ & $\mathrm{G}_{2}$ & LoS & $\mathrm{P}$ & $\mathrm{S}_{3}$ & $\mathrm{O}_{3}$ & $\mathrm{G}_{3}$ & LoS \\
\hline Smell and Taste & 41.6 & 39.8 & 45.5 & 45.3 & $* *$ & 41.6 & 33.5 & 47.8 & 46.8 & $* *$ & 41.6 & 28.4 & 44.6 & 43.1 & $*$ \\
\hline $\begin{array}{l}\text { Body and } \\
\text { Cobsistency }\end{array}$ & 26.3 & 22.6 & 27.1 & 27.1 & ** & 26.3 & 18.7 & 27.5 & 26.2 & NS & 26.3 & 15.2 & 27.1 & 23.8 & ** \\
\hline Color and Texture & 17.2 & 14.4 & 19.2 & 18.9 & NS & 17.2 & 12.9 & 19.4 & 17.3 & ** & 17.2 & 10.1 & 19.2 & 15.4 & NS \\
\hline Total Score & 85.1 & 76.8 & 91.8 & 91.3 & & 85.1 & 65.1 & 94.7 & 90.3 & & 85.1 & 53.7 & 90.9 & 82.3 & \\
\hline
\end{tabular}

$\mathrm{P}=$ plain, $\mathrm{S}_{1}, \mathrm{O}_{1}, \mathrm{G}_{1}=5 \%$ of strawberry, orange and grape juice respectively, $\mathrm{S}_{2}, \mathrm{O}_{2}, \mathrm{G}_{2}=10 \%$ of strawberry, orange and grape juice respectively, $\mathrm{S}_{3}, \mathrm{O}_{3}, \mathrm{G}_{3}=15 \%$ of strawberry, orange and grape juice respectively, LoS= Level of significance, ${ }^{*}=$ significant at $1 \%$ level, ${ }^{* *}=$ significant at $5 \%$ level, NS $=$ Non significant

Table 2: Effect of physical characteristics on quality of plain and different types of fruit yoghurt.

\begin{tabular}{|c|c|c|c|c|c|c|c|c|c|c|c|c|c|c|c|}
\hline \multirow{3}{*}{$\begin{array}{l}\text { Chemical } \\
\text { characteristics }\end{array}$} & \multicolumn{15}{|c|}{ Different types of fruit yoghurt } \\
\hline & \multicolumn{5}{|c|}{$5 \%$ fruit juice } & \multicolumn{5}{|c|}{$5 \%$ fruit juice } & \multicolumn{5}{|c|}{$5 \%$ fruit juice } \\
\hline & $\mathbf{P}$ & $\mathbf{S}_{1}$ & $\mathrm{O}_{1}$ & $\mathbf{G}_{1}$ & LoS & $\mathbf{P}$ & $\mathrm{S}_{2}$ & $\mathrm{O}_{2}$ & $\mathbf{G}_{2}$ & LoS & $\mathbf{P}$ & $\mathbf{S}_{3}$ & $\mathrm{O}_{3}$ & $\mathbf{G}_{3}$ & LoS \\
\hline Moisture (\%) & 74.03 & 74.06 & 74.30 & 73.59 & $* *$ & 74.03 & 74.19 & 74.66 & 73.21 & $* *$ & 74.03 & 74.29 & 75.12 & 72.82 & ** \\
\hline Total solids (\%) & 25.97 & 25.94 & 25.69 & 26.40 & ** & 25.97 & 25.81 & 25.33 & 26.78 & ** & 25.97 & 25.70 & 24.79 & 27.17 & ** \\
\hline Acidity (\%) & 0.66 & 0.78 & 0.77 & 0.74 & NS & 0.66 & 0.79 & 0.78 & 0.75 & NS & 0.66 & 0.81 & 0.79 & 0.77 & NS \\
\hline Fat $(g)$ & 4.5 & 4.3 & 4.27 & 4.27 & $* *$ & 4.5 & 4.1 & 4.05 & 4.05 & $* *$ & 4.5 & 3.9 & 3.82 & 3.82 & $* *$ \\
\hline Protein (g) & 3.5 & 3.36 & 3.33 & 3.33 & * & 3.5 & 3.22 & 3.16 & 3.16 & * & 3.5 & 3.08 & 3.00 & 3.00 & * \\
\hline $\mathrm{CHO}(\mathrm{g})$ & 16.60 & 16.83 & 16.64 & 17.37 & ** & 16.60 & 17.06 & 16.68 & 18.14 & $* *$ & 16.60 & 17.29 & 16.72 & 18.91 & ** \\
\hline Ash (\%) & 0.71 & 0.67 & 0.68 & 0.69 & $* *$ & 0.71 & 0.64 & 0.66 & 0.68 & $* *$ & 0.71 & 0.62 & 0.64 & 0.67 & $* *$ \\
\hline
\end{tabular}

$\mathrm{P}=$ plain, $\mathrm{S}_{1}, \mathrm{O}_{1}, \mathrm{G}_{1}=5 \%$ of strawberry, orange and grape juice respectively, $\mathrm{S}_{2}, \mathrm{O}_{2}, \mathrm{G}_{2}=10 \%$ of strawberry, orange and grape juice respectively, $\mathrm{S}_{3}, \mathrm{O}_{3}, \mathrm{G}_{3}=15 \%$ of strawberry, orange and grape juice respectively, LoS = Level of significance, ${ }^{*}=$ significant at $1 \%$ level, ${ }^{* *}=$ significant at $5 \%$ level, NS= Non significant

Table 3: Effect of chemical characteristics on quality of plain and different types of fruit yoghurt. 
ash content of yoghurt with $15 \%$ levels of grape juice was somewhat lower than that of plain yoghurt but differences in ash content between and among the treatments was not significant $(\mathrm{P}>0.05)$. The average values of protein content of $\mathrm{P}, \mathrm{S}_{3}, \mathrm{O}_{3}$ and $\mathrm{G}_{3}$ types of yoghurt were 3.50, $3.08,3.00$ and 3.00 g respectively (Table 3 ). The carbohydrate content was highest in $\mathrm{G}_{3}$ (15\% grape juice) type yoghurt and the lowest in plain $(\mathrm{P})$ yoghurt. Statistical analysis showed that there were significant $(\mathrm{P}<0.05)$ differences among the different types of fruit yoghurt in terms of carbohydrate content. As juice concentration increase, the nutrient content of yoghurt also increased.

\section{Comparison of Microbiological characteristics of fruit yoghurts}

Microbiological characteristics are indicators of safety, quality and shelf life of prepared yoghurt. Total viable count, total coliform count and yeast and Mold count of the fruit yoghurt was determined 0, 5, 7 and 9 days. Results obtained are shown in (Table 4, 5 \& 6).

\section{Yoghurts with 5\% fruit juice}

There was significant difference $(\mathrm{P}<0.05)$ in term of total viable organisms count and yeast \& mold count among the fruit yoghurts with $5 \%$ juice. But differences in total coliform count between plain and fruit juice yoghurt and among the different level of juice yoghurt were not significant $(\mathrm{P}<0.01)$. Highest total viable organism $(\mathrm{Log} \mathrm{cfu} / \mathrm{gm})$ was recorded for $G_{1}$ type yoghurt and the lowest value was recorded for plain (P) yoghurt (Table 4). Higher organism count in yoghurt with different fruit juice might be due to increased level of juice in yoghurt.

\section{Yoghurts with $10 \%$ fruit juice}

Table 5 shows that yoghurt with $10 \%$ grape juice contain highest number of total viable count, coliform and but yoghurt sample with $10 \%$ strawberry juice shows highest number yeast \& mold. All organisms were found in low number in plain yoghurt. The differences in coliform count between plain and $10 \%$ juice yoghurt were not significant while for other sample it were significant.

\section{Yoghurts with 15\% fruit juice}

The total viable bacterial count, coliform count, yeast and mold count of plain yoghurt and yoghurt with $15 \%$ strawberry $\left(\mathrm{S}_{3}\right)$, orange $\left(\mathrm{O}_{3}\right)$ and grape $\left(\mathrm{G}_{3}\right)$ were presented in (Table 6). Results revealed that except coliform count, differences in other organisms count were significant $(\mathrm{P}<0.05)$. Lowest coliform count was observed in $15 \%$ strawberry juice yoghurt and highest in orange and grape juice yoghurt. Highest total viable organism and yeast \& mold count were recorded for $15 \%$ grape juice yoghurt and lowest for plain yoghurt.

\section{Discussion}

The research was conducted to develop fortified fruit yoghurt with acceptable physical, chemical and microbiological quality. Three different fruit (strawberry, orange and grape) with three different concentrations $(5 \%, 10 \%$ and $15 \%)$ are used in this experiment. It is obvious from the study that the $10 \%$ orange juice $\left(\mathrm{O}_{2}\right.$ type $)$ improves the organoleptic quality and chemical characteristics of fruit yoghurt at the refrigeration temperature. On the other hand, all kinds of chemical characteristics are also acceptable comparing with other fruit yoghurt. The acidity of all fruit yoghurt was increased because fruit (strawberry, orange and grape) contain more acid than milk. The fat, protein and ash content of fruit yoghurt were decreased comparing with plain/ control yoghurt because fruit (strawberry, orange and grape) contain lower fat, protein and ash. The moisture content of fruit yoghurt was increased because fruit (strawberry, orange and grape) contain slightly more water than milk. Total solids content fruit yoghurt was decreased

\begin{tabular}{|c|c|c|c|c|c|c|c|c|c|c|c|c|c|c|c|c|}
\hline \multirow{3}{*}{ Parameter } & \multicolumn{16}{|c|}{ Different types of fruit yoghurt with $5 \%$ fruit juice } \\
\hline & \multicolumn{4}{|c|}{$\mathbf{p}$} & \multicolumn{4}{|c|}{$\mathrm{S}_{1}$} & \multicolumn{4}{|c|}{$\mathrm{O}_{1}$} & \multicolumn{4}{|c|}{$\mathbf{G}_{1}$} \\
\hline & 0 & 5 & 7 & 9 & 0 & 5 & 7 & 9 & 0 & 5 & 7 & 9 & 0 & 5 & 7 & 9 \\
\hline TVC, Log cfu/g & 2 & 5 & 5.39 & 5.60 & 1.6 & 5.08 & 5.18 & 5.48 & 1.7 & 5 & 5.43 & 5.70 & 2.1 & 5.95 & 6.15 & 6.55 \\
\hline Coliform, MPN/g & 0 & 0 & 10 & 25 & 0 & 0 & 6 & 15 & 0 & 0 & 6 & 18 & 0 & 0 & 10 & 18 \\
\hline Yeast \& Mold, cfu/g & 0 & 0 & 12 & 25 & 0 & 0 & 10 & 35 & 0 & 0 & 10 & 30 & 0 & 0 & 12 & 40 \\
\hline
\end{tabular}

( $P=$ plain, $\mathrm{S}_{1}, \mathrm{O}_{1}, \mathrm{G}_{1}=5 \%$ of strawberry, orange and grape juice respectively)

Table 4: Microbiological Quality of fruit yoghurts with $5 \%$ fruit juice.

\begin{tabular}{|c|c|c|c|c|c|c|c|c|c|c|c|c|c|c|c|c|}
\hline \multirow{3}{*}{ Parameter } & \multicolumn{16}{|c|}{ Different types of fruit yoghurt with $10 \%$ fruit juice } \\
\hline & \multicolumn{4}{|c|}{$\mathbf{p}$} & \multicolumn{4}{|c|}{$\mathrm{S}_{2}$} & \multicolumn{4}{|c|}{$\mathrm{O}_{2}$} & \multicolumn{4}{|c|}{$\mathbf{G}_{2}$} \\
\hline & 0 & 5 & 7 & 9 & 0 & 5 & 7 & 9 & 0 & 5 & 7 & 9 & 0 & 5 & 7 & 9 \\
\hline TVC, Log cfu/g & 1.5 & 5 & 5.39 & 5.60 & 1.9 & 5.08 & 5.20 & 5.34 & 2.1 & 4.95 & 5.39 & 5.76 & 2.2 & 6 & 6.08 & 6.55 \\
\hline Coliform, MPN/g & 0 & 0 & 10 & 25 & 0 & 0 & 5 & 12 & 0 & 0 & 6 & 20 & 0 & 0 & 10 & 15 \\
\hline Yeast \& Mold, cfu/g & 0 & 0 & 12 & 25 & 0 & 0 & 8 & 28 & 0 & 0 & 10 & 22 & 0 & 0 & 11 & 35 \\
\hline
\end{tabular}

( $P=$ plain, $\mathrm{S}_{2}, \mathrm{O}_{2}, \mathrm{G}_{2}=10 \%$ of strawberry, orange and grape juice respectively)

Table 5: Microbiological Quality of fruit yoghurts with 10\% fruit juice.

\begin{tabular}{|c|c|c|c|c|c|c|c|c|c|c|c|c|c|c|c|c|}
\hline \multirow{3}{*}{ Parameter } & \multicolumn{16}{|c|}{ Different types of fruit yoghurt with $15 \%$ fruit juice } \\
\hline & \multicolumn{4}{|c|}{$\mathbf{p}$} & \multicolumn{4}{|c|}{$\mathrm{S}_{3}$} & \multicolumn{4}{|c|}{$\mathrm{O}_{3}$} & \multicolumn{4}{|c|}{$\mathbf{G}_{3}$} \\
\hline & 0 & 5 & 7 & 9 & 0 & 5 & 7 & 9 & 0 & 5 & 7 & 9 & 0 & 5 & 7 & 9 \\
\hline TVC, Log cfu/g & 1.4 & 5 & 5.39 & 5.60 & 1.6 & 4.90 & 5.11 & 5.30 & 1.9 & 5 & 5.43 & 5.72 & 2.1 & 5.90 & 6.15 & 6.48 \\
\hline Coliform, MPN/g & 0 & 0 & 10 & 25 & 0 & 0 & 0 & 10 & 0 & 0 & 5 & 18 & 0 & 0 & 7 & 22 \\
\hline Yeast \& Mold, cfu/g & 0 & 0 & 12 & 25 & 0 & 0 & 0 & 8 & 0 & 0 & 5 & 15 & 0 & 0 & 5 & 11 \\
\hline
\end{tabular}

( $P=$ plain, $\mathrm{S}_{3}, \mathrm{O}_{3}, \mathrm{G}_{3}=15 \%$ of strawberry, orange and grape juice respectively)

Table 6: Microbiological Quality of fruit yoghurts with $15 \%$ fruit juice. 
Citation: Hossain MN, Fakruddin M, Islam MN (2012) Quality Comparison and Acceptability of Yoghurt with Different Fruit Juices. J Food Process Technol 3:171. doi:10.4172/2157-7110.1000171

Page 5 of 5

because of lower content of total solids. The grape yoghurt contains more carbohydrate than plain/control yoghurt. Fruits which are used for this research purposes contain more acid. For this reason the number of coliform, total viable count, yeast and molds are acceptable but the microbial load is increased highly in normal temperature for the time being and it is not acceptable after 9 days. The strawberry juice contains high amount of acid. For this reason strawberry fruit yoghurt is highly acidic but $5 \%$ strawberry juice ( $\mathrm{S}_{1}$ type) yoghurt are acceptable because its $\mathrm{pH}$ and acidity is acceptable for human consumption. Above $5 \%$ level of strawberry juice is not suitable for fruit yoghurt making. The quality of fruit yoghurt can be improved by proper pasteurization of milk and fruit juice and necessary steps of sanitary conditions.

\section{Conclusion}

Yoghurt fortified with $10 \%$ orange juice is the best in all quality aspects among the yoghurts formulated in this study. Yoghurts with $5 \%$ fruit juice are also of acceptable in quality but vary with each other slightly in organoleptic properties. $15 \%$ strawberry juice is not suitable for yoghurt making. This formulation and quality findings may be useful for yoghurt industries to produce new variety of yoghurts.

\section{References}

1. Munzur MM, Islam MN, Akhter S, Islam MR (2004) Effect of different levels of vegetable oil for the manufacture of Dahi from skim milk. Asian-Aust J Anim Sci 17: 1019-1025.

2. Mansour AA, Khalifa MY, Hanafy NM (1994) Utilization of some dairy by product in yogurt manufacture. Egyptian J Food Sci 22: 87-97.

3. Perdigon G, de Moreno de LeBlanc A, Valdez J, Rachid M, Blanc AM (2002) Role of yoghurt in the prevention of colon cancer. Eur J Clin Nutr 56: 565-568.

4. Kamruzzaman M, Islam MN, Rahman MM, Parvin S, Rahman MF (2002) Evaporation rate of moisture from Dahi (yoghurt) during storage at refrigerated condition. Pak J Nutr 1: 209-211.

5. Kumar P, Mishra HN (2004) Mango soy fortified set yoghurt: effect of stabilize addition on physicochemical, sensory and textural properties. Food Chem 87: 501-507

6. Boghra VR, Mathur ON (2000) Physico-chemical status of major milk constituents and minerals at various stages of shrikhand preparation. J Food Sci Technol 37: 111-115

7. Desai SR, Toro VA, Joshi SV (1994) Utilization of different fruit in the manufacture of yogurt. Journal of Dairy Science 47: 870-874.

8. Shukla FC, Jain SC, Sandhu kS (1987) Technological and Physiological aspects of yoghurt and fruit yoghurt. Indian Journal of Dairy Science 90: 12 .

9. Nahar A, Al-Amin M, Alam SMK, Wadud A, Islam MN (2007) A Comparative Study on the Quality of Dahi (Yoghurt) Prepared from Cow, Goat and Buffalo Milk. International Journal of Dairy Science 2: 260-267.

10. Guven M, Karaca OB (2002) The effects of varying sugar content and fruit concentration on the physical properties of vanilla and fruit ice-cream type frozen yogurts. Int J Dairy Technol 55: 27-31.

11. Hossain MN, Fakruddin M, Islam MN (2011) Effect of Chemical Additives on the shelf life of tomato juice. American Journal of Food Technology 6: 914-923.

12. AOAC (2002) Official Methods of Analysis (17thedn), Association of Official Agricultural Chemists. Washington D.C.

13. Aggarwala AC, Sharma RM, (1961) A laboratory Manual of Milk Inspection. (4thedn) Asia Publishing House, New Delhi, India.

14. Ranganna S (1976) Manual of Analysis of Fruit \& Vegetable Products. Tata McGraw-Hill Publ. Co. Ltd., New Delhi, India.

15. Begum J, Nahar A, Islam MN, Rahman MM (2011) Qualitative Characteristics of Dahi Prepared from Non-Fat-Dry Milk Fortified with Vegetable Oil. Bangladesh Research Publications Journal 6: 35-45

16. Harrigan W (1998) Laboratory Methods in Food Microbiology. (3rdedn) Academic Press, San Diego.

17. APHA (American Public Health Association) (1998) Standard Methods for examination of Dairy Products $\left(20^{\text {th }}\right.$ ed.). Washington D.C, Newyork.

18. Biswas AA (1997) Effect of Banana (Musa sapientum) leaf on the keeping quality of raw milk. M.S.Thesis, Department of Dairy Science, Bangladesh Agricultural University, Mymensingh 24-32.

19. Osundahunsi OF, Amosu D, Ifesan BOT (2007) Quality Evaluation and Acceptability of Soy-yoghurt with Different Colours and Fruit Flavours. American Journal of Food Technology 2: 273-280.

20. Keating KR, White CH (1990) Effect of alternative sweeteners in plain and fruitflavored yogurts. Journal of Dairy Science 73: 54-62. 